\title{
Instruments for evaluating financial management capacity among the elderly: an integrative literature review
}

Sabine Possa Marronil

Graciane Radaelli, ${ }^{2,3}$ Irenio Gomes da Silva Filho, Mirna Wetters Portuguez ${ }^{1,2}$

\section{Abstract}

Objective: To identify tools available in literature for assessing the financial management capacity of elderly persons with and without cognitive deficit or impairment. Methods: An integrative literature review was performed. Scientific publications indexed in the PubMed, LILACS (Latin American and Caribbean Health Sciences Literature), Psychology Index and Cochrane Library databases by November 2015 were evaluated. Results: Of the 609 articles obtained from the databases, 29 were considered eligible for this review, and involved 11 instruments for the evaluation of financial management capacity, the most cited of which was the Financial Capacity Instrument (FCI). Conclusion: There are several scales and instruments available which are used to investigate both daily and instrumental activities of daily living, which allow the independence and effective functioning of the elderly on a day to day basis to be verified. Non-Brazilian literature also describes specific instruments for the assessment of financial management capacity. However, no references to a specific scale that evaluates this construct and which has been validated and adapted for the Brazilian population were identified.

\footnotetext{
Pontifícia Universidade Católica do Rio Grande do Sul (PUC-RS), Instituto de Geriatria e Gerontologia Programa de Pós-Graduação em Gerontologia Biomédica. Porto Alegre, RS, Brasil.

2 Pontifícia Universidade Católica do Rio Grande do Sul (PUC-RS), Instituto do Cérebro (INSCER), Porto Alegre, RS, Brasil;

3 Universidade Federal de São Paulo/Escola Paulista de Medicina, São Paulo, SP, Brasil.
}

Funding: Pontifical Catholic University of Rio Grande do Sul (PROBOLSA-PUCRS)
Keywords: Elderly. Financial Management Capacity. Integrative Review. 


\section{INTRODUCTION}

The medical advances of recent decades have resulted in an increase in the life expectancy of the population. According to the World Health Organization (WHO), the number of people over 60 will double by the year $2050^{1}$. Often, however, living longer does not mean living with better quality of life or an adequate health situation. Due to cognitive decline and subsequent losses in financial management capacity, the increase of the elderly population represents a number of challenges for society ${ }^{2}$.

In the process of normal aging, some basic cognitive functions may be affected, such as memory and attention ${ }^{3}$. At the same time, decreases in sensory and perceptual capacities and, later, diminished executive functions can occur. Problems related to the loss of financial skills can occur in the normal aging process and may be aggravated in cases of associated diseases ${ }^{4}$. In people with acquired cognitive impairment, sudden changes in cognitive functioning can have a significant negative impact on financial management and judgment ${ }^{5-7}$.

Financial management capacity is a multidimensional construct that involves a broad spectrum of pragmatic, conceptual and judgmental activities ranging from basic banknote and coin identification skills to more complex activities such as paying bills and managing checkbooks and bank accounts ${ }^{4,8}$. In addition, financial management capacity is the instrumental activity of daily life which is considered the main predictor of the ability or otherwise of the elderly to live alone ${ }^{2,5,9}$. Determining when an individual is no longer able to manage their own finances can be a complex task. Despite the importance of the subject and a number of proposed models, an adequate manner of measuring financial management capacity in elderly patients has not yet been established in literature.

The objective of the present study was to identify and describe the instruments available in literature for the evaluation of the financial management capacity of elderly individuals with or without cognitive impairment. In addition, the review focused on identifying instruments that included performance based measures and the direct examination of tasks or activities in a natural or clinical environment.
These measures included standardized scoring procedures assessed on the basis of task completion or responses to survey questions (such as vignette or problem-based questions).

\section{METHOD}

A review was carried out to identify and describe the instruments used to assess the financial management capacity of elderly people with or without cognitive impairment, based on the integrative literature review method ${ }^{10}$. Five methodological steps were used: a) problem identification; b) literature search; c) evaluation of the data; d) integration of data and; e) presentation of the results.

Once the topic was defined, the question of the research was elaborated as follows: "Which instruments assess the financial management capacity or ability of elderly persons with or without cognitive impairment and what are the characteristics of scope of these instruments?".

The following were used as eligibility criteria: a) type of study: studies of any research design that assessed the financial management capacity or ability of elderly persons with or without cognitive impairment and that used some type of specific instrument to evaluate such capacity; b) types of participants: elderly persons with or without cognitive impairment; c) date or language restrictions were not applied.

Scientific publications indexed in the PubMed, LILACS (Latin American and Caribbean Health Sciences Literature), Psychology Index and Cochrane Library databases by November 2015 were evaluated.

To search for the articles in the databases, the following MeSH terms were used: (1) Terms related to Financial Management Capacity: "Financial Management", "Financial Assessment", "Financial Abilities", "Financial capacity", "Financial Skills"; (2) Terms related to the participants: "Aged" OR "Elderly" OR "Mild Cognitive Impairment" OR "Alzheimer Disease" OR "Dementia", among others; and (3) Terms related to the evaluation instruments: "Psychiatric Status Rating Scales" OR "Weights and Measures" OR "Measures and Weights" OR "Weights" OR "Measures" OR "Measure" OR "Scales" OR "Subscale" OR "Assessment" 
First, two researchers working in duplicate independently assessed the titles and abstracts of the citations from the databases for the selection of potentially eligible studies. The full texts of these citations were then sought out for a detailed evaluation, which included the studies that met the previously established eligibility criteria.

An instrument constructed for the purposes of this study was used for the extraction of data from the included articles. This tool specified the following items: title, type of research, place of research, number of patients, characteristics of participants, year of publication, objective, methodology, instrument used for assessing financial management capacity, conclusion.

The material was analyzed and selected by similarity of content and an analysis category was constructed, which was specific instruments for the assessment of financial management capacity.

\section{RESULTS}

The initial literature search identified 609 citations. After the analysis of titles and abstracts, 502 citations were excluded as they did not meet the previously defined eligibility criteria. The complete texts of the remaining 64 articles were reviewed, of which 29 were selected and included. This total included eleven specific instruments for the evaluation of financial management capacity. The process of the selection of the works is shown in Figure 1.

Chart 1 identifies the instruments included in the research studies, their author(s), year and country of origin, as well as the references found in the study regarding the use of the instrument. Eleven specific instruments for evaluating financial management capacity in the elderly were categorized. Among these, the most frequently found in the studies in literature was the Financial Capacity Instrument (FCI $)^{5,6,11-22}$. Correlated instruments, which presented objectives that complemented the research, such as the semistructured clinical interview (SCIFC) ${ }^{23}$, the reduced version of the FCI (FCI-SF) ${ }^{24}$, the prior/premorbid financial capacity form (PFCF) $)^{12,21}$ and the current financial capacity information form $(\mathrm{CFCF})^{19,21}$, were also identified. These other instruments were developed on the basis of the conceptual framework of the FCI. Most instruments were developed in the USA (8) $(72.7 \%)^{5,15,21,23-27}$, (Chart 1).

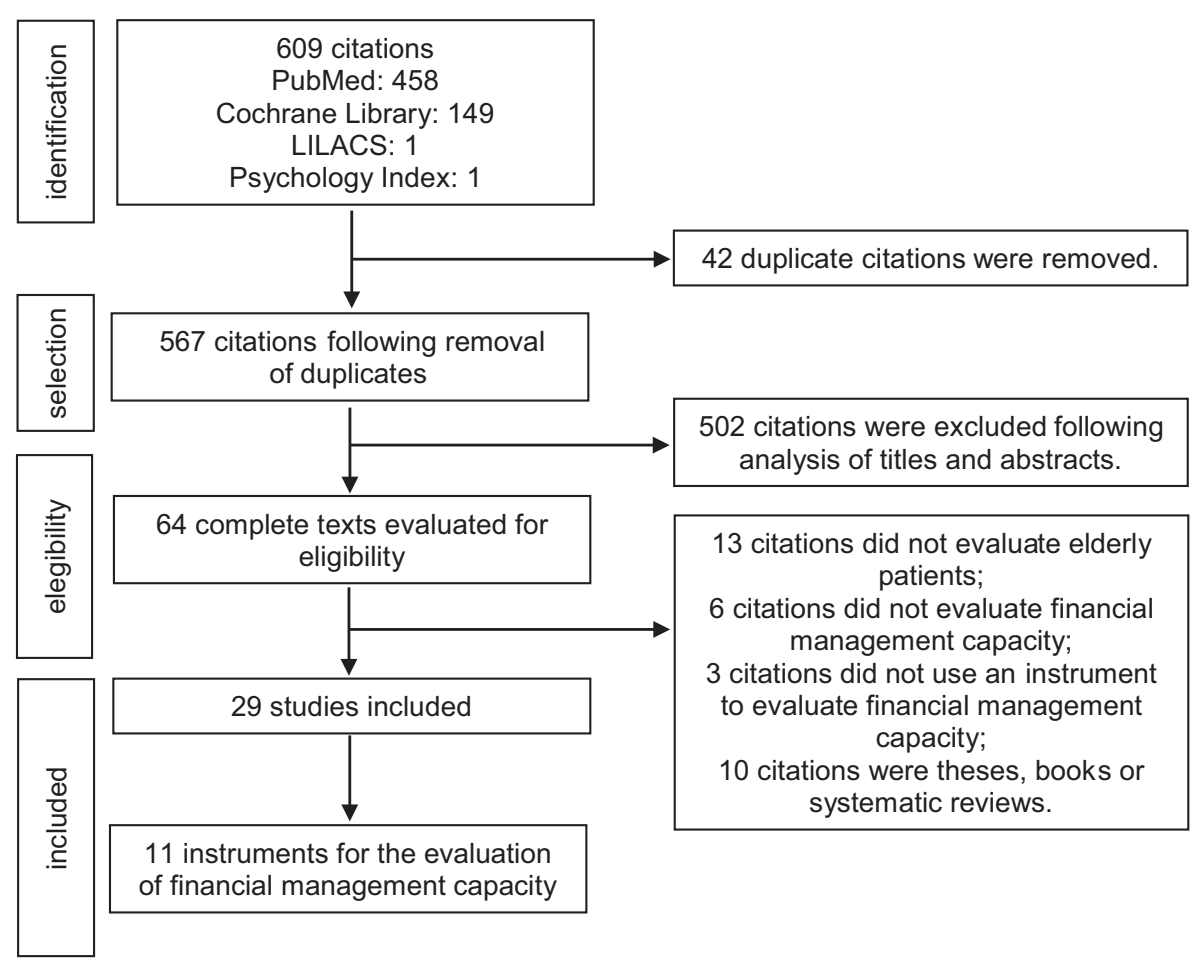

Figure 1. Flowchart of selection of studies and instruments. Porto Alegre, Rio Grande do Sul, 2015. 
Chart 1. Identification of instruments included in the study. Porto Alegre, Rio Grande do Sul, 2015.

\begin{tabular}{|c|c|c|}
\hline Specific Instruments & $\begin{array}{l}\text { Validation } \\
\text { Author, Year, Country }\end{array}$ & Studies found in research that used the instrument \\
\hline $\begin{array}{l}\text { Managing Money Scale (ILS } \\
\mathrm{MM} \text { ) }\end{array}$ & $\begin{array}{l}\text { Loeb, } 1996^{27}, \\
\text { USA }\end{array}$ & Mackin and Areán ${ }^{28} ;$ Wood et al. ${ }^{29}$ \\
\hline $\begin{array}{l}\text { Financial Capacity Instrument } \\
(\mathrm{FCI})\end{array}$ & $\begin{array}{l}\text { Marson et al., } 2000^{5} \text {; Griffith } \\
\text { et al., } 2003^{15} \text {, } \\
\text { USA }\end{array}$ & $\begin{array}{l}\text { Martin et al. }{ }^{6} \text {; Stoeckel et al }{ }^{11} \text {; Triebel et al. }{ }^{13} \text {; Griffith } \\
\text { et al. }{ }^{16} \text {; Triebel et al. }{ }^{12} \text {; Sherod et al. } .^{17} \text {; Martin et } \\
\text { al. } .^{18} \text {; Okonkwo et al. } .^{19} \text {; Griffith et al. } .^{14} \text {; Okonkwo et } \\
\text { al. }^{20} \text {; Griffith et al. }{ }^{15} \text {; Wadley et al. } .^{21} \text {; Earnst et al. }{ }^{22} \text {; } \\
\text { Marson et al. }{ }^{5}\end{array}$ \\
\hline $\begin{array}{l}\text { Prior/Premorbid Financial } \\
\text { Capacity Form (PFCF) }\end{array}$ & $\begin{array}{l}\text { Wadley et al., } 2003^{21} \text {, } \\
\text { USA }\end{array}$ & Triebel et al. ${ }^{12}$; Wadley et al..$^{21}$ \\
\hline $\begin{array}{l}\text { Current Financial Capacity Form } \\
\text { (CFCF) }\end{array}$ & $\begin{array}{l}\text { Wadley et al., } 2003^{21} \text {, } \\
\text { USA }\end{array}$ & Okonkwo et al. ${ }^{19}$ \\
\hline $\begin{array}{l}\text { Financial Competence Assessment } \\
\text { Tool (FCAT) }\end{array}$ & $\begin{array}{l}\text { Sakuraba et al., } 2004^{30} \text {, } \\
\text { Japan }\end{array}$ & Sakuraba et al. ${ }^{30}$ \\
\hline $\begin{array}{l}\text { Measure of Awareness of } \\
\text { Financial Skills (MAFS) }\end{array}$ & $\begin{array}{l}\text { Cramer et al., } 2004^{31} \text {, } \\
\text { Canada }\end{array}$ & Van Wielingen et al. ${ }^{32}$; Cramer et al. ${ }^{31}$ \\
\hline $\begin{array}{l}\text { Financial Competence Assessment } \\
\text { Inventory (FCAI) }\end{array}$ & $\begin{array}{l}\text { Kershaw and Webber, } 2008^{33} \text {, } \\
\text { Australia }\end{array}$ & Pachana et al. ${ }^{34} ;$ Kershaw and Webber ${ }^{33}$ \\
\hline $\begin{array}{l}\text { Financial decision-making } \\
\text { questionnaire (FDMQ) }\end{array}$ & $\begin{array}{l}\text { Cole and Denburg, } 2008^{25} \text {, } \\
\text { USA }\end{array}$ & Shivapour et al. ${ }^{35}$ \\
\hline $\begin{array}{l}\text { Semi-Structured Clinical Interview } \\
\text { for Financial Capacity (SCIFC) }\end{array}$ & $\begin{array}{l}\text { Marson et al., } 2009^{23} \text {, } \\
\text { USA }\end{array}$ & Marson et al. ${ }^{23}$ \\
\hline $\begin{array}{l}\text { Financial Capacity Instrument } \\
\text { Short Form (FCI-SF) }\end{array}$ & $\begin{array}{l}\text { Gerstenecker et al., } 2015^{24} \text {, } \\
\text { USA }\end{array}$ & Gerstenecker et al. ${ }^{24}$ \\
\hline $\begin{array}{l}\text { Lichtenberg Financial Decision } \\
\text { Rating Scale (LFDRS) }\end{array}$ & $\begin{array}{l}\text { Lichtenberg et al., } 2015^{26} \text {, } \\
\text { USA }\end{array}$ & Lichtenberg et al. ${ }^{26}$ \\
\hline
\end{tabular}

Chart 2 displays the instruments in terms of the form of assessment of the participants, as well as the design of the validation study, the objectives and the characteristics of scope. All studies of this sample had a cross-sectional design. The population studied varied from cognitively normal elderly persons (controls) and comparisons with patients with mild cognitive impairment (MCI) and Alzheimer's disease (AD) in the mild and moderate phases. In addition, in order to perform the analysis and complement information on functionality, many studies used information reported by informants. 
Chart 2. Description of instruments for the assessment of financial management capacity among the elderly: forms of assessment, study design, objectives and characteristics of scope. Porto Alegre, Rio Grande do Sul, 2015.

\begin{tabular}{|c|c|c|c|c|}
\hline $\begin{array}{l}\text { Specific } \\
\text { instruments }\end{array}$ & $\begin{array}{l}\text { Forms of } \\
\text { evaluation }\end{array}$ & $\begin{array}{l}\text { Design of study, } \\
\text { validation and } \\
\text { sample }\end{array}$ & $\begin{array}{l}\text { Objectives of } \\
\text { instrument }\end{array}$ & Characteristics / scope \\
\hline $\begin{array}{l}\text { Managing Money } \\
\text { Scale (ILS MM) }\end{array}$ & PB & $\begin{array}{l}\text { Cross-sectional } \\
\text { MCI, dementia and } \\
\text { psychiatric disease }\end{array}$ & 4 tasks & $\begin{array}{l}\text { Count money; complete financial } \\
\text { calculations; pay bills; take precautions } \\
\text { with money }\end{array}$ \\
\hline $\begin{array}{l}\text { Financial Capacity } \\
\text { Instrument }(\mathrm{FCI})^{5,15}\end{array}$ & PB & $\begin{array}{l}\text { Controlled cross- } \\
\text { sectional } \\
73 \text { individuals } \\
23 \mathrm{C} ; 30 \text { mild AD; } \\
20 \text { moderate AD }\end{array}$ & 9 domains & $\begin{array}{l}\text { Basic monetary skills; financial concepts; } \\
\text { cash transactions; check management; } \\
\text { banking management; financial } \\
\text { discernment; bill payment; knowledge } \\
\text { about actions and organization of assets } \\
\text { (corroborated with a relative/ informant); } \\
\text { investment decisions }\end{array}$ \\
\hline $\begin{array}{l}\text { Prior/Premorbid } \\
\text { Financial Capacity } \\
\text { Form }(\text { PFCF })^{21}\end{array}$ & $\mathrm{P}, \mathrm{I}$ & $\begin{array}{l}\text { Cross-sectional } \\
20 \mathrm{AD} \text { and } 20 \\
\text { family members } \\
23 \mathrm{C} \text { and } 23 \text { family } \\
\text { member informants }\end{array}$ & 8 FCI domains & $\begin{array}{l}\text { Self-reported instrument for patients } \\
\text { and informants, identifies previous } \\
\text { experiences and skills on financial } \\
\text { experiences regarding the variables of the } \\
\text { FCI, previously described }\end{array}$ \\
\hline $\begin{array}{l}\text { Current Financial } \\
\text { Capacity Form } \\
(\mathrm{CFCF})^{21}\end{array}$ & $\mathrm{P}, \mathrm{I}$ & $\begin{array}{l}\text { Cross-sectional } \\
20 \mathrm{AD} \text { and } 20 \\
\text { family members } \\
23 \mathrm{C} \text { and } 23 \text { family } \\
\text { member informants }\end{array}$ & 8 FCI domains & $\begin{array}{l}\text { Self-reported instrument for patients and } \\
\text { informants. Investigates current financial } \\
\text { functioning. It uses the same conceptual } \\
\text { model as the FCI and provides an overall } \\
\text { evaluation as well as judgments about the } \\
\text { current functioning }\end{array}$ \\
\hline $\begin{array}{l}\text { Financial Competence } \\
\text { Assessment Tool } \\
(\text { FCAT })^{30}\end{array}$ & PB & $\begin{array}{l}\text { No information } \\
\text { Publication of } \\
\text { original article in } \\
\text { Japanese. }\end{array}$ & $\begin{array}{l}6 \text { domains } \\
\text { of financial } \\
\text { competence }\end{array}$ & $\begin{array}{l}\text { Basic monetary skills; conceptual financial } \\
\text { knowledge; use of banking institution; } \\
\text { cash transactions; financial discernment; } \\
\text { understanding of receipts and expenses }\end{array}$ \\
\hline $\begin{array}{l}\text { Measure of Awareness } \\
\text { of Financial Skills } \\
\text { (MAFS) }^{31}\end{array}$ & PB, P, I & $\begin{array}{l}\text { Cross-sectional } \\
\text { controlled } \\
70 \text { individuals } \\
10 \text { elderly persons } \\
\text { with dementia and } \\
10 \text { informants; } \\
25 \text { normal } \\
\text { individuals and } 25 \\
\text { informants }\end{array}$ & $\begin{array}{l}6 \text { tasks related } \\
\text { to finances, } \\
\text { as well as a } \\
\text { questionnaire } \\
\text { applied to the } \\
\text { participant and } \\
\text { the informant }\end{array}$ & $\begin{array}{l}\text { Identification of money; count money; } \\
\text { cash/change transactions; interpret an } \\
\text { account/invoice; filling in the check; } \\
\text { checkbook management }\end{array}$ \\
\hline $\begin{array}{l}\text { Financial Competence } \\
\text { Assessment Inventory } \\
(\text { FCAI })^{33}\end{array}$ & $\mathrm{~PB}$ & $\begin{array}{l}\text { Controlled cross- } \\
\text { sectional } \\
178 \text { individuals } \\
59 \text { with no cognitive } \\
\text { impairment } \\
\text { and } 4 \text { groups } \\
\text { with cognitive } \\
\text { impairment: } 36 \\
\text { with acquired brain } \\
\text { injury; } 29 \text { with } \\
\text { schizophrenia; } 22 \\
\text { with dementia; } 32 \\
\text { with intellectual } \\
\text { impairment }\end{array}$ & 6 subscales & $\begin{array}{l}\text { Daily financial skills; financial } \\
\text { discernment; wealth management; } \\
\text { financial skills related to cognitive } \\
\text { functioning; debt management; support } \\
\text { sources }\end{array}$ \\
\hline
\end{tabular}


continued from Chart 2

\begin{tabular}{|c|c|c|c|c|}
\hline $\begin{array}{l}\text { Specific } \\
\text { instruments }\end{array}$ & $\begin{array}{l}\text { Forms of } \\
\text { evaluation }\end{array}$ & $\begin{array}{l}\text { Design of study, } \\
\text { validation and } \\
\text { sample }\end{array}$ & $\begin{array}{l}\text { Objectives of } \\
\text { instrument }\end{array}$ & Characteristics / scope \\
\hline $\begin{array}{l}\text { Financial decision- } \\
\text { making questionnaire } \\
(\text { FDMQ })^{25}\end{array}$ & PB & $\begin{array}{l}\text { Cross-sectional } \\
218 \text { subjects } \\
116 \text { residents of the } \\
\text { community and } 102 \\
\text { young adults from a } \\
\text { university course }\end{array}$ & $\begin{array}{l}5 \text { domains } \\
\text { of financial } \\
\text { knowledge and } \\
\text { the ability to } \\
\text { make decisions }\end{array}$ & $\begin{array}{l}\text { personal finances; purchase impulse; } \\
\text { low-precision investment; financial } \\
\text { management; financial behavior }\end{array}$ \\
\hline $\begin{array}{l}\text { Semi-Structured } \\
\text { Clinical Interview for } \\
\text { Financial Capacity } \\
(\text { SCIFC })^{23}\end{array}$ & PB, P & $\begin{array}{l}\text { Cross-sectional; } \\
\text { controlled } \\
261 \text { individuals } \\
75 \mathrm{C} ; 58 \mathrm{MCI} ; \\
97 \text { mild AD; } 31 \\
\text { moderate AD }\end{array}$ & $\begin{array}{l}8 \text { domains, } \\
\text { seven main } \\
\text { and one } \\
\text { experimental } \\
\text { (based on } \\
\text { assessment } \\
\text { and clinical } \\
\text { judgement) }\end{array}$ & $\begin{array}{l}\text { Basic monetary skills; knowledge of } \\
\text { financial concepts; cash transactions; } \\
\text { checkbook management; bank account } \\
\text { management; financial judgment; } \\
\text { payment of invoices / bills; knowledge } \\
\text { about assets and equity (information } \\
\text { corroborated with family member/ } \\
\text { informant) }\end{array}$ \\
\hline $\begin{array}{l}\text { Financial Capacity } \\
\text { Instrument Short } \\
\text { Form }\left(\text { FCI-SF) }{ }^{24}\right.\end{array}$ & PB & $\begin{array}{l}\text { Cross-sectional; } \\
\text { non-controlled } \\
1344 \text { cognitively } \\
\text { normal elderly } \\
\text { persons } \\
\text { Paired for age and } \\
\text { educational level }\end{array}$ & $\begin{array}{l}5 \text { constructs } \\
\text { and a total. } \\
\text { Evaluate } \\
\text { the time of } \\
\text { response to } \\
\text { items }\end{array}$ & $\begin{array}{l}\text { knowledge about currency; knowledge } \\
\text { of financial concepts; troubleshooting; } \\
\text { knowledge/use of checks; knowledge/use } \\
\text { of bank statements }\end{array}$ \\
\hline $\begin{array}{l}\text { Lichtenberg Financial } \\
\text { Decision Rating Scale } \\
(\text { LFDRS })^{26}\end{array}$ & $\mathrm{P}$ & $\begin{array}{l}\text { Cross-sectional } \\
\text { study with a } \\
\text { qualitative focus } \\
\text { Validation of } \\
\text { content and } \\
\text { inter-evaluator } \\
\text { concordance } \\
5 \text { patients (1 THB, } \\
1 \text { dementia and } 3 \\
\text { normal individuals }\end{array}$ & $\begin{array}{l}\text { Multiple choice } \\
\text { questions, } \\
\text { separated into } \\
\text { sessions }\end{array}$ & $\begin{array}{l}\text { Conscience of AD sufferers of financial } \\
\text { situation; psychological vulnerability; } \\
\text { current financial transactions; undue } \\
\text { influence; financial exploitation }\end{array}$ \\
\hline
\end{tabular}

PB: performance based assessment; P: information reported by patient; I: information reported by family member/informant/caregiver; C: controls; DA: Alzheimer's disease; MCI: mild cognitive impairment.

In terms of the objectives and the characteristics of scope of the instruments found in the validation studies, variations from four to nine questions, constructs, items, domains, scales/subscales and/ or tasks were identified. Among the most cited were investigation of basic monetary ability, knowledge about financial concepts, cash transactions, check management and payment of bills.

\section{DISCUSSION}

The present integrative review allowed the findings in literature to be visualized and, in addition, the description of the main instruments available for the evaluation of financial management capacity in the elderly. These results will provide health professionals and researchers in the field of gerontology with information regarding the choice of instruments for the evaluation of this construct, as well as knowledge of the studies that support the instruments in populations of elderly people with or without cognitive impairment. It should be noted that deficits in the ability to manage one's own finances may be a sign of cognitive impairment and should be considered in the clinical evaluation of the elderly ${ }^{7,36-39}$. 
In the present study, 11 instruments were classified as specific (Chart 1) for the assessment of financial management capacity and categorized in terms of their form and the scope of their evaluation of the issues, and whether based on performance, patient or caregiver information, as previously reported by other researchers ${ }^{36,40,41}$.

Financial management capacity is mediated by higher cognitive functions and includes a broad set of basic skills (identifying and counting money, accounting) as well as complex skills (such as checkbook and bank statement management and investment decisions, among other tasks) 5,15,21,24,39. Specific instruments that include the greatest possible amount of relevant information are necessary for an effective understanding of this function in the elderly. Financial management is considered an important ability for the elderly to live independently $2,58,9,42$. However, this task should consider the context in which the elderly person is inserted, together with their current and previous experiences.

There are various instruments that investigate financial management capacity. Engel et al. in $2016^{41}$ carried out a systematic review in order to identify instruments available in the English language that contained items that evaluated the financial management capacity of adults with acquired cognitive impairment. A total of 88 instruments were found, 44 of which identified this condition based on performance evaluation, while the remainder were based on self-reporting or the reports of companions. Of these, 24 were developed for the elderly population with dementia. The authors concluded that most of the instruments were developed for the elderly and few were comprehensive in scope, that is, they did not encompass all the aspects related to financial management ability. In addition, it was important to evaluate the criteria of the authors regarding the key domains used to evaluate financial management skills (in this case, nine domains). They considered the domains of basic monetary skills, conceptual financial knowledge (or knowledge of their own finances), calculations and cash transactions, checkbook handling, bank and extract management, bill payment, budget management, monitoring and regulation of spending and others (such as understanding of investments, insurance, fraud detection, fees and loan negotiation), all of which were important for the understanding of the construct $^{41}$.

Analyzing this context, one criticism that can be made of the instruments identified in this research is that they are not available in Brazilian Portuguese nor validated for the Brazilian population. The Pfeffer Scale (Functional Assessment Questionnaire-FAQ) can be used to investigate functional capacity of instrumental tasks of daily living among the elderly, but includes few items for assessing financial management skills ${ }^{43}$.

No specific instruments developed in Brazil and based on performance tasks were found. Instead, there are scales of measures obtained from the reports of relatives/caregivers and from the patients themselves that assess basic and instrumental functional activities, as well as investigating how the individual performs day-to-day shopping and money management tasks, with only one or two questions related to financial management.

A study of the translation and cultural adaptation of the DAFS-R (Direct Assessment of Functional Status) for Brazilian Portuguese (DAFS-BR) was carried out in a group of 89 elderly people previously classified as normal controls, those with MCI and AD. The results identified good sensitivity and specificity for the identification of MCI and AD and good internal consistency (Cronbach's Alpha=0.78) in the total sample. They concluded that the DAFS-BR can document the degree of severity in functional impairment in Brazilian elderly persons. However, the DAFS is not a specific instrument for evaluating financial management, but a subscale; it should not therefore be used uniquely to determine financial capacity. Although it is a performancebased assessment and contains tasks of identifying currency, counting money, making change, filling in a check and calculating a bill, it does not include other important components such as financial judgment and knowledge of financial concepts ${ }^{44-46}$.

Most of the studies identified in this study had cross-sectional designs and populations comprising elderly persons with MCI and/or AD, controlled by healthy elderly community members and/or informants. Few of the identified instruments were constructed and validated for the financial management assessment of cognitively normal elderly 
persons, and thus did not detect subtle differences in this group. Financial management capacity is an important instrumental activity of daily living for the independent and autonomous life of the elderly ${ }^{5,15,47}$. According to some authors, there is a great risk of patients with $\mathrm{MCI}$ progressing to $\mathrm{AD}$, and the evaluation of financial management can help in the early identification of changes in their health profiles ${ }^{7,8,38}$.

Instruments with a comprehensive scope of items, which provide classification based on multiple domains of financial management ability, assist in the identification of elderly individuals with specific limitations in this area, who may require supervision or intervention. This category of instruments may be useful in clinical, research and forensic settings ${ }^{8,42,48}$.

The studies by Daniel Marson et al. are especially notable in this context (Chart 2).

The Financial Capacity Instrument (FCI) is a standardized psychometric instrument ${ }^{5,15,47}$ that evaluates domains of financial skills when correlating cognitively normal elderly groups with dementia (mild or moderate, especially AD) and MCI patients. It is based on performance and aims to comprehensively assess nine domains of financial activity ${ }^{5,6,12}$.

Other instruments that complement this investigation and take the FCI as a starting point have been designed. The Prior/Premorbid Financial Capacity Form (PFCF) ${ }^{5,15,21,23}$ is a self-reported instrument for patients and informants that identifies experiences and skills regarding the variables of the FCI. Since current financial capacity may vary from individual to individual, the evaluation of the prior knowledge of subjects about financial experiences can aid in the control of the analyzes. The instrument is administered to the study participant and their informant and classified as: could do without help, could do but needed help, could not do even with help $p^{15,21}$.

The Current Financial Capacity Form (CFCF) $)^{19,21}$ is another self-reported instrument developed to report the information of patients and their informants, identifying the current level of functioning of subjects in relation to financial skills. It provides an overall judgment as well as judgments on current functioning in eight financial domains and in 20 associated tasks.
The Semi-Structured Clinical Interview for Financial Capacity (SCIFC) is a relatively brief, semi-structured clinical interview that assesses seven core financial domains and overall financial capacity. The clinician evaluates individuals according to their judgment of capacity (able, marginally capable, incapable) ${ }^{23}$.

The FCI has limited clinical utility as it contains a great many items and is long for the purposes of administration in a single clinical appointment ${ }^{24}$. For this reason, the authors developed a reduced instrument with five domains which is applicable in fifteen minutes, and is capable of detecting functional impairment in the initial phase of AD, the FCI- SF (Short Form) $)^{24}$. It was based on the items most strongly associated with the progression of AD in a sample of MCI patients.

The complementary assessments based on previous and current abilities to deal with finances and also described by informants are important for a thorough clinical analysis and the investigation of particular questions of this context. Often there is some discrepancy between the information reported by caregivers and that reported by the patient ${ }^{49}$. Under conditions of independent functioning, this may not have a direct impact on the life of the elderly. However, under conditions of cognitive deficits, as in the case of MCI, the perception of functioning reported by both parties can be quite different, due to the reduction of the awareness of deficits presented by the elderly, who often perceive themselves as capable of performing certain tasks without realizing the difficulties involved. Or, on the contrary, in situations where the family takes precautions on behalf of the elderly person, the right to carry out tasks related to finances is withdrawn, and the elderly individual then loses their autonomy and independence.

Studies using the FCI have sought to determine the cognitive mechanisms that underly changes in instrumental activities of daily living (IADL) in patients with MCI and to improve our understanding of the relationship between cognitive dysfunction and functional restriction, as there is no consensus on which IADL are affected in $\mathrm{MCI}^{20,40}$. Griffith et al. ${ }^{15}$ identified four of the nine domains evaluated by the FCI that differed between participants with MCI and controls (conceptual financial knowledge, cash transactions, bank statement management, and bill payment). Neuropsychological assessment can 
objectively identify and monitor the presence of cognitive deficits and the possibilities of evolution to $\mathrm{AD}$, helping families and the patient to plan the future and make decisions on financial management issues. Niccolai et al., conducted a two-year follow-up study using FCI and neuropsychological assessment in MCI patients. The work identified reduced performance in functions of visual memory, attention and knowledge of arithmetic concepts as predictors of decline in these patients. They emphasized that clinical assessments should consider the neurocognitive skills of arithmetic, visual memory and processing speed in patients with $\mathrm{MCI}^{38}$.

Elderly persons with mild AD performed worse than controls in the nine domains and in the general financial capacity of the initial FCI. In the one year review, there was a considerable deterioration in overall financial management capacity ${ }^{18}$. The one-year decline in simple and complex financial skills underscores the importance of the financial supervision and planning of families to support patients diagnosed with AD. This assistance, to compensate for the decline in the basic judgment and the ability to count, seeks to protect such individuals from fraud and exploitation schemes ${ }^{50,51}$. Some abilities can remain stable in this period, such as naming coins/banknotes, and understanding and prioritizing bills ${ }^{18}$. Professionals who work with the elderly must understand and identify the reduction of the financial decision-making capacity of such individuals and assist them in order to reduce potential financial abuse and improper exploitation ${ }^{8,37,52}$.

Marson et al. ${ }^{23}$ and Gardiner et al..$^{53}$ state that there is no accepted standard for evaluating clinical judgments of financial capacity ${ }^{23,53}$. Kershaw and Webber ${ }^{33}$ developed an instrument suitable for use in Australia, where there is no universally accepted definition of financial competence and few uniform guidelines for assessing financial competence. The FCAI, with 38 items, presents six subscales to be evaluated: daily financial skills, financial judgments, real estate management, cognitive functioning related to financial tasks, account management and support resources. There are also four subscales to evaluate the processes involved in the financial competence, such as understanding, appreciation, reasoning and expression of choices.
Due to the different social and economic contexts, as well as the laws in force in Brazil and the characteristics of the population being evaluated, the choice of evaluation instruments is an important factor. Many Brazilian elderly people live on pensions, retirement funds or government benefits, with their income restricted to maintaining basic expenses. For this reason, it is difficult to use instruments to assess the ability to manage finances that have not been developed for this reality and its context. It is understood that the lack of experience and disadvantages in this area occurs because of the low financial resources available to such individuals, as well as their low educational attainment and a lack of opportunity to invest, acquire or conserve resources.

Assessing the progressive loss of functional capacity to perform activities of daily living (functional disability) is an essential characteristic for the diagnosis of dementia, the adequate orientation of the patient and his/her caregivers, and to identify the effect of pharmacological and non-pharmacological interventions.

Issues involving financial management capacity in the elderly often arise due to the concerns of family members, health professionals or, in some cases, the elderly themselves ${ }^{34}$. Several studies and instruments can be found in non-Brazilian literature, such as those identified in this research. However, in Brazilian literature, there is no single instrument based on the performance of specific tasks that includes questions for informants and the elderly, and contains performance tasks related to this advanced instrumental activity.

In Brazil, the clinical evaluation for such issues is carried out through questionnaires and scales based on information provided by family members/caregivers or the elderly themselves, about how they "use money and makes purchases" in the context of financial abuse and misappropriation. This information, along with psychometric/neuropsychological assessment (which will investigate cognitive functions such as memory, language, attention, spatial visibility, logical reasoning, ability to perform calculations, etc.) will provide an understanding of the ability of elderly persons to perform such tasks. 
There are some limitations in the identification and selection of articles in this study and possibly in relation to the selection of search terms. For our population, no specific instruments were identified that address the multidimensional issues and adequacy of the assessment of financial management skills in the elderly.

It is therefore important to consider, in clinical evaluation, the investigation of financial management capacity in the elderly, and that these assessments can, as well as collecting information from the elderly and their relatives/caregivers, include tasks based on performance, as the early and accurate identification of individuals with compromised financial skills will help to safely protect and control the economic resources and emotional well-being of the elderly and their families. In addition, it will also ensure greater security, autonomy and independence for this age group.

\section{CONCLUSION}

In this integrative review we identified and selected the instruments available in literature for the evaluation of the financial management capacity of the elderly. Eleven specific instruments were selected, which included in their validations the evaluation of elderly individuals with or without cognitive impairment and eight instruments that included measures based on performance. The FCI instrument featured in the largest number of studies and researches.

\section{REFERENCES}

1. World Health Organization. Number of people over 60 years set to double by 2050; major societal changes required. Geneva: WHO; 2015.

2. Caboral-Stevens M, Medetsky M. The construct of financial capacity in older adults. J Gerontol Nurs. 2014;40(8):30-7.

3. Glisky EL. Changes in cognitive function in human aging. In: Riddle DR, editor. Brain aging: models, methods, and mechanisms. Boca Raton: CRC Press; 2007. p. 4-20.
In relation to the Brazilian elderly population, no specific instruments based on performance tasks were identified that considered differences in schooling and life experience.

Based on non-Brazilian studies on the subject under study, it is necessary to develop an instrument adapted to the reality of Brazilian elderly persons, contemplating the socioeconomic and cultural characteristics that this construct involves. Such an instrument should contain basic and advanced tasks. It should be noted that instruments that include many items of comprehension may not be appropriate for the Brazilian context, as they may not elucidate clearly the reality of the elderly and their experiences. In addition, it is also important to develop instruments with a greater number of samples that contemplate both cognitively normal elderly persons and those with cognitive impairment, especially in cases of MCI. Performance-based tasks cannot be neglected, as these have good clinical applicability and can be combined with patient and informant/family member questionnaires, always considering the current and prior functional ability of the elderly. The use of environmentally friendly tasks, designed to bring the situation under assessment closer to the problems faced on a day-to-day basis and to reality, as well as tasks involving technology (such as machines used for cash withdrawals or for the payment of bills, mobile devices/applications and sites) are also important tasks to be considered in research, especially taking into account the constant changes that are taking place in the current socioeconomic context of Brazil and the world.

4. Widera E, Steenpass V, Marson D, Sudore R. Finances in the older patient with cognitive impairment: "He didn't want me to take over". JAMA. 2011;305(7):698-706.

5. Marson DC, Sawrie SM, Snyder S, McInturff B, Stalvey $\mathrm{T}$, Boothe A, et al. Assessing financial capacity in patients with Alzheimer disease: a conceptual model and prototype instrument. Arch Neurol. 2000;57(6):877-84. 
6. Martin RC, Triebel KL, Kennedy RE, Nicholas AP, Watts RL, Stover NP, et al. Impaired financial abilities in Parkinson's disease patients with mild cognitive impairment and dementia. Parkinsonism Relat Disord. 2013;19(11):986-90.

7. Marson D. Investigating functional impairment in preclinical Alzheimer's Disease. J Prev Alzheimers Dis. 2015;2(1):4-6.

8. Marson D. Conceptual models and guidelines for clinical assessment of financial capacity. Arch Clin Neuropsychol. 2016;31(6):541-53.

9. Dreer LE, Devivo MJ, Novack TA, Marson DC. Financial capacity following traumatic brain injury: a six-month longitudinal study. Rehabil Psychol. 2012;57(1):5-12.

10. Whittemore R, Knafl K. The integrative review: updated methodology. J Adv Nurs. 2005;52(5):546-53.

11. Stoeckel LE, Stewart CC, Griffith HR, Triebel K, Okonkwo OC, Den Hollander JA, et al. MRI volume of the medial frontal cortex predicts financial capacity in patients with mild Alzheimer's disease. Brain Imaging Behav. 2013;7(3):282-92.

12. Triebel KL, Martin R, Griffith HR, Marceaux J, Okonkwo OC, Harrell L, et al. Declining financial capacity in mild cognitive impairment: A 1-year longitudinal study. Neurology. 2009;73(12):928-34.

13. Triebel KL, Okonkwo OC, Martin R, Griffith HR, Crowther M, Marson DC. Financial capacity of older african americans with amnestic mild cognitive impairment. Alzheimer Dis Assoc Disord. 2010;24(4):365-71.

14. Griffith HR, Okonkwo OC, Den Hollander JA, Belue K, Lanza S, Harrell LE, et al. Brain Proton MRS is correlated with financial abilities in patients with Alzheimer's Disease. Brain Imaging Behav. 2007;1:23-9.

15. Griffith HR, Belue K, Sicola A, Krzywanski S, Zamrini E, Harrell L, et al. Impaired financial abilities in mild cognitive impairment: a direct assessment approach. Neurology. 2003;60(3):449-57.

16. Griffith HR, Stewart CC, Stoeckel LE, Okonkwo OC, Den Hollander JA, Martin RC, et al. Magnetic resonance imaging volume of the angular gyri predicts financial skill deficits in people with amnestic mild cognitive impairment. J Am Geriatr Soc. 2010;58(2):265-74.

17. Sherod MG, Griffith HR, Copeland J, Belue K, Krzywanski S, Zamrini EY, et al. Neurocognitive predictors of financial capacity across the dementia spectrum: normal aging, mild cognitive impairment, and Alzheimer's disease. J Int Neuropsychol Soc. 2009;15(2):258-67.
18. Martin R, Griffith HR, Belue K, Harrell L, Zamrini E, Anderson B, et al. Declining financial capacity in patients with mild Alzheimer disease: a oneyear longitudinal study. Am J Geriatr Psychiatry. 2008;16(3):209-19.

19. Okonkwo OC, Wadley VG, Griffith HR, Belue K, Lanza S, Zamrini EY, et al. Awareness of deficits in financial abilities in patients with mild cognitive impairment: going beyond self-informant discrepancy. Am J Geriatr Psychiatry. 2008;16(8):650-9.

20. Okonkwo OC, Wadley VG, Griffith HR, Ball K, Marson DC. Cognitive correlates of financial abilities in mild cognitive impairment. J Am Geriatr Soc. 2006;54(11):1745-50.

21. Wadley VG, Harrell LE, Marson DC. Self- and informant report of financial abilities in patients with Alzheimer's disease: reliable and valid? J Am Geriatr Soc. 2003;51(11):1621-6.

22. Earnst KS, Wadley VG, Aldridge TM, Steenwyk AB, Hammond AE, Harrell LE, et al. Loss of financial capacity in Alzheimer's Disease: the role of working memory. Aging, Neuropsychol Cogn. 2001;8(2):109-19.

23. Marson DC, Martin RC, Wadley V, Griffith HR, Snyder S, Goode PS, et al. Clinical interview assessment of financial capacity in older adults with mild cognitive impairment and Alzheimer's disease. J Am Geriatr Soc. 2009;57(5):806-14.

24. Gerstenecker A, Eakin A, Triebel K, Martin R, Swenson-Dravis D, Petersen RC, et al. Age and education corrected older adult normative data for a short form version of the Financial Capacity Instrument. Psychol Assess. 2015;28(6):737-49.

25. Cole CA, Denburg NL. Financial Decision Making Questionnaire (FDMQ). Iowa City: University of Iowa Carver College of Medicine, Department of Neurology; 2008.

26. Lichtenberg PA, Stoltman J, Ficker LJ, Iris M, Mast B. A Person-Centered approach to financial capacity assessment: preliminary development of a new rating scale. Clin Gerontol. 2015;38(1):49-67.

27. Loeb PA. Independent Living Scales: additional record forms. San Antonio: Psychological Corp; 1996.

28. Mackin RS, Areán PA. Impaired financial capacity in late life depression is associated with cognitive performance on measures of executive functioning and attention. J Int Neuropsychol Soc. 2009;15(5):793-8.

29. Wood S, Rakela B, Liu PJ, Navarro AE, Bernatz S, Wilber KH, et al. Neuropsychological profiles of victims of financial elder exploitation at the los angeles county elder abuse forensic center. J Elder Abuse Negl. 2014;26(4):414-23. 
30. Sakuraba Y, Kumawzawa Y, Matsuda O.

Development of the Financial Competency Assessment Tool (FCAT): a study of the reliability and validity of the FCAT. Bull Tokyo Gakugei Univ Sect I Sci Educ. 2004;55:131-9.

31. Cramer K, Tuokko HA, Mateer CA, Hultsch DF. Measuring awareness of financial skills: reliability and validity of a new measure. Aging Ment Health. 2004;8(2):161-71.

32. Van Wielingen LE, Tuokko HA, Cramer K, Mateer CA, Hultsch DF. Awareness of financial skills in dementia. Aging Ment Health. 2004;8(4):374-80.

33. Kershaw MM, Webber LS. Assessment of financial competence. Psychiatry, Psychol Law. 2008;15(1):40-55.

34. Pachana NA, Byrne GJ, Wilson J, Tilse C, Pinsker DM, Massavelli B, et al. Predictors of financial capacity performance in older adults using the Financial Competence Assessment Inventory. Int Psychogeriatr. 2014;26(6):921-7.

35. Shivapour SK, Nguyen CM, Cole CA, Denburg NL. Effects of age, sex, and neuropsychological performance on financial decision-making. Front Neurosci. 2012;6:1-9.

36. Flint L, Sudore R, Widera E. Assessing financial capacity impairment in older adults. J Am Soc Aging. 2012;36(2):59-65.

37. Peterson JC, Burnes DP, Caccamise PL, Mason A, Henderson CR, Wells MT, et al. Financial exploitation of older adults: a population-based prevalence study. J Gen Intern Med. 2014;29(12):1615-23.

38. Niccolai LM, Triebel KL, Gerstenecker A, McPherson TO, Cutter GR, Martin RC, et al. Neurocognitive predictors of declining financial capacity in persons with mild cognitive impairment. Clin Gerontol. 2017;40(1):14-23.

39. Marson DC. Clinical and ethical aspects of financial capacity in dementia: a commentary. Am J Geriatr Psychiatry. 2013;21(4):392-0.

40. Jekel K, Damian M, Wattmo C, Hausner L, Bullock $\mathrm{R}$, Connelly PJ, et al. Mild cognitive impairment and deficits in instrumental activities of daily living: a systematic review. Alzheimers Res Ther. 2015;7(1):1-20.

41. Engel L, Bar Y, Beaton DE, Green RE, Dawson DR. Identifying instruments to quantify financial management skills in adults with acquired cognitive impairments. J Clin Exp Neuropsychol. 2016;38(1):76-95.
42. Sousa LB, Simões MR, Firmino H, Peisah C. Financial and testamentary capacity evaluations: procedures and assessment instruments underneath a functional approach. Int Psychogeriatr. 2014;26(2):217-28.

43. Dutra MC, Ribeiro RS, Pinheiro SB, Melo GF, Carvalho GA. Accuracy and reliability of the Pfeffer Questionnaire for the Brazilian elderly population. Dement Neuropsychol. 2015;9(2):176-83.

44. Loewenstein DA, Amigo E, Duara R, Guterman A, Hurwitz D, Berkowitz N, et al. A new scale for the assessment of functional status in Alzheimer's disease and related disorders. J Gerontol. 1989;44(4):114-21.

45. McDougall GJ, Becker H, Vaughan PW, Acee TW, Delville CL. The revised direct assessment of functional status for independent older adults. Gerontologist. 2010;50(3):363-70.

46. Pereira FS, Oliveira AM, Diniz BS, Forlenza OV, Yassuda MS. Cross-cultural adaptation, reliability and validity of the DAFS-R in a sample of Brazilian older adults. Arch Clin Neuropsychol. 2010;25(4):335-43.

47. Marson DC. Loss of financial competency in dementia: Conceptual and empirical approaches. Aging Neuropsychol Cogn. 2001;8(3):164-81.

48. Sousa L, Vilar M, Firmino H, Simões MR. Financial Capacity Assessment Instrument (IACFin): Development and Qualitative Study Using Focus Groups. Psychiatry Psychol Law. 2015;22(4):571-85.

49. Giannouli V, Tsolaki M. A Neglected Drama for Elders: Discrepancy Between Self-Perception and Objective Performance Regarding Financial Capacity in Patients With Cognitive Deficits. Psychological Thought. 2015;8(2):142-7.

50. Spreng RN, Cassidy BN, Darboh BS, DuPre E, Lockrow AW, Setton R, et al. Financial Exploitation Is Associated With Structural and Functional Brain Differences in Healthy Older Adults. J Gerontol Ser A Biol Sci Med Sci. Epub ahead print 28 mar. 2017.

51. Wood SA, Liu PJ, Hanoch Y, Estevez-Cores S. Importance of Numeracy as a Risk Factor for Elder Financial Exploitation in a Community Sample. J Gerontol Ser B Psychol Sci Soc Sci. 2016;71(6):978-86.

52. Lichtenberg PA. Financial exploitation, financial capacity, and Alzheimer's disease. Am Psychol. 2016;71(4):312-20.

53. Gardiner PA, Byrne GJ, Mitchell LK, Pachana NA. Financial capacity in older adults: a growing concern for clinicians. Med J Aust. 2015;202(2):82-5. 